\title{
Strategic change and narrative turn perspectives in media texts: learning and coopetition in strategising
}

\author{
Rauno Rusko \\ Faculty of Social Sciences, \\ Management and Organizations, \\ University of Lapland, \\ P.O.B. 122, FI96101 Rovaniemi, Finland \\ Email: rauno.rusko@ulapland.fi
}

\begin{abstract}
For consultants, media texts are a channel to market their services, capabilities and knowledge. Media texts are a significant tool for participating and directing the general pulse of management and strategising. This study follows a narrative turn in emphasising the importance of micro-stories in strategising and strategy research. An empirical analysis of media texts on the web about strategic change revealed that today's professional consultants are expressing more cooperation-based perspectives compared with competitionbased perspectives. However, because the main paradigm of societies and economies is competition, the general underlying tendency is based on the tension between competition and cooperation (coopetition). Furthermore, media texts show that strategising is not based on top-down management, but on empowerment processes where the participants are discussing and even deciding the aims of the organisation. In addition, this study concerns the relationship between knowledge management, theory in use and strategy as practice, providing some implications.
\end{abstract}

Keywords: intra-organisational coopetition; emergent strategy; organisational learning; theory-in-use; SAP; strategy as practice; strategic change; narrative turn.

Reference to this paper should be made as follows: Rusko, R. (2015) 'Strategic change and narrative turn perspectives in media texts: learning and coopetition in strategising', Int. J. Strategic Change Management, Vol. 6, No. 1, pp.35-58.

Biographical notes: Rauno Rusko, PhD, Lic.Soc.Sc., graduated from the University of Lapland and from the University of Oulu. He is Lecturer of management and entrepreneurship at the University of Lapland. He has been also Lecturer of Economics in the University of Vaasa and in the University of Lapland. His research activities focus on cooperation, coopetition, strategic management, supply chain management and entrepreneurship mainly in the branches of information communication technology, forest industry and tourism. His articles appeared in the European Management Journal, Forest Policy and Economics, Industrial Marketing Management, Managing Leisure, International Journal of Innovation in the Digital Economy and International Journal of Tourism Research among others. 


\section{Introduction}

The blog of a strategy consultant serves as a trademark about his/her services, capabilities and knowledge about how to strategise and activate an organisation and its representatives for better business in the future. Often, it is also the condensed description about the espoused purposes of strategy workshops in which the consultant is one of the actors and even the main organiser of strategising. The consultant business leans on human resources and especially knowledge-based resources, which are actually linked with themes of knowledge management and organisational learning (Ordóñes de Pablos, 2004). Furthermore, consultants aim to provide incremental value or even components for a competitive advantage to their business clients. New strategic tools and perspectives might generate new and updated knowledge-based resources to the firms and the customers of the consultants. Knowledge is an essential part of strategising, which also means that knowledge management (KM) is an underlying feature in strategic change.

Strategic management is frequently linked with knowledge-based resources and a resource-based view (RBV), where the focus is on the resources of a sustainable competitive advantage (see, e.g., Ordóñes de Pablos, 2004; Afiouni, 2013). Organisational learning is an essential part of efforts to develop the knowledge-based resources of the firm (Ordóñes de Pablos, 2004). Strategic change needs organisational learning in the forms of theory-in-use (Argyris and Schön, 1978), and it is associated with the issue of the routines and competencies of the firm (Monteiro and Pianna, 2012). Although RBV and KM are important to the strategic change and organisational learning of the organisation, this study focuses on a discussion of the strategic change associated with practices and routines that the consultants express in their blogs in addition to organisational learning (and theoryin-use). The discussion, which emphasises the role of strategic practices especially in discourses, is known as the strategy as practice (SAP) perspective (Laine and Vaara, 2007).

Blogs are often micro-stories, typical for contemporary 'Facebook society' (see, e.g., Dalsgaard, 2008). Furthermore, these micro-stories might be a kind of narrative displaying the attitudes of consultants, managers and others about strategising as they interact as well as showcasing formalised techniques for strategy making (Fenton and Langley, 2011).

This study focuses on media texts (blogs and chats/comments) about strategic change written by strategy consultants, CEOs of consulting firms or strategic educators. The strategising culminates in the change process (Pettigrew et al., 2001). Therefore, this study emphasises theoretical strategic change discussions and the features, contents and discourses of media texts associated with strategic change.

According to strategic change studies, learning and emergence are important parts of change management. Even institutional change might have effects on the strategies of firms, learning and finally, the competitive advantage of the firms (Monteiro and Pianna, 2012). Mintzberg et al. (1998) defined 10 different schools of strategic thinking. One of these schools is the learning school, which emphasises the importance of (changing) emergent strategy. Although there have been some attempts to consider SAP even on the city level (Kornberger and Clegg, 2011), the SAP perspective mainly is based on emphasising the emergent and grassroots nature of strategic activities (Jarzabkowski, 2005; Osborne and Ballantyne, 2012; Rusko, 2012; Achtenhagen et al., 2013), which is not necessarily parallel to planned strategy. Furthermore, the theory-in-use perspective 
is focused on the relevance of learning and in the context of strategic actions (Argyris, 1991; Argyris and Schön, 1996).

Emergent strategy is focused on actual phases and practices of the strategy process. One source for practice-based strategy and the movement of the 'practice turn' (see, e.g., Orlikowski, 1992, 2000; Orr, 1996; Schatzki et al., 2001; Whittington, 2003, 2006; Jarzabkowski et al., 2007; Chia and MacKay, 2007; Hällgren and Lindahl, 2012; Ramsey, 2014; Zundel, 2013), which emphasises the dialogue and interaction between the members of organisation in the research of strategic management, is the SAP perspective.

The 'practice turn' in strategic management, which consists of dialogue, interaction and learning, is focused on organisational changes. However, this practice turn perspective omits the systematic consideration of the relevance of competitive and cooperative actions associated with strategic management and especially with strategic change. This research notes, based on case study material, the importance of paradoxical tension and the simultaneity of cooperation and competition, that is, coopetition, as a part of strategic management.

This paper studies the contents and discourses of strategic change by basing its analysis on media texts. The consultants are the representatives of professionalism in the field of organisational change (see, e.g., Kipping and Kirkpatrick, 2013). Their public written opinions in blogs describe at least the espoused theory of strategic change. In addition, the analysis covers several chats and comments, which are typically written in less measured terms, reflecting the theory-in-use perspectives of consultants and participants in the pages focused on strategic change.

This study has the following structure: the literature review consists of two parts, the contemporary literature of SAP and theory-in-use perspectives regarding the tendency of the practice turn and comparisons between theory-in-use and SAP. The research design considers the case study material, introduces the research method and describes the research process. After that, the main results of the empirical part are considered. In the discussion part of the paper, these results are combined with contemporary discussions about SAP, theory-in-use and intra-organisational coopetition in the context of strategy making. Finally, conclusions show the most important findings of the study, restrictions of the results, managerial implications and the most important themes for further research.

\section{Literature review}

\subsection{Perspectives for strategic change in strategic management literature}

In the management literature, there are several alternative perspectives to studying strategic change in addition to linkages between strategic change and RBV, knowledge management, sustainable knowledge-based competitive advantage (Ordóñes de Pablos, 2004; Monteiro and Pianna, 2012), emergent strategy and the learning school introduced by Mintzberg et al. (1998). This study introduces two other perspectives that also have strong links with strategic change and emergent strategy. Both theory-in-use and SAP perspectives are popular ways to understand strategic change (see, e.g., Styhre, 2002; Lundin and Söderholm, 1995; Whittington, 1996, 2006), also having connections with emergent strategy and the learning school (see, e.g., Rusko, 2012). 


\subsubsection{Theory in use}

The theory-in-use perspective describes the actual practical actions of individuals, which typically differ from external (pretended) actions and aims. The latter ones are called espoused theory. Two contrasting theories, that is, theory in use vs. espoused theory, which was introduced by Argyris and Schön (1974), resemble several other dichotomies, such as the 'knowing-doing gap' (cf. MacLean and MacIntosh, 2012). Strategic change is realised in various forms of learning, according to the theory-in-use perspective (Miller and Tsang, 2011). Thus, theory-in-use discussions have a close relationship with strategy and strategising (see, e.g., Argyris, 1976, 1977; Argyris and Schön, 1978, 1983).

According to Argyris (1976, p.367), a theory-in-use model "hypothesised that human behaviour, in any situation, represents the most satisfactory solution people can find consistent with their governing values or variables, such as achieving a purpose as others define it, winning, suppressing negative feelings, and emphasising rationality". In organisations and in the actions of leaders, there is a gap between the espoused theory and theory in use. Furthermore, Argyris (1976, p.373) noticed that it is necessary to study theory in use, but there is a lack of empirical data about these kinds of actions.

Theory in use is the fundamental guiding principle of an individual. It might be even risky to change one's theories in use because they represent a source of confidence that one has in functioning effectively in one's world (Argyris, 1976, p.370). Argyris and Schön (1974) connect these two concepts firmly with learning. They introduce two kinds of learning: single-loop learning and double-loop learning. The difference between these two is based on the fact that the espoused theory of action, which is the most general model of action, is based on single-loop learning, and double-loop learning is proposed as providing feedback and more effective decision-making (Argyris, 1976, p.363). Singleloop learning emphasises general control and the thought that 'individuals are expected to be articulate about their purposes, goals, and so forth, and simultaneously control the others and the environment in order to ensure achievement of their goals.' In other words, their theory in use is, despite their learning, unchanging. But in double-loop learning, the control is more tolerant, which enables changes in the theory in use of individuals and organisations (see also Sorama, 2008). Thus, double-loop learning is more demanding because it involves the detection and correction of error and requires changes in underlying policies, assumptions and goals (Argyris, 1980, p.291). Argyris and Schön $(1974,1978)$ use the example of a thermostat: it is 'a single-loop learner because it detects when the room is too hot or too cold. A thermostat would be a double-loop learner if it questioned why it was set at 65 degrees or why it was measuring heat' (Argyris, 1980, p.291). Thus, significant strategic change merits double-loop learning.

Although there is a lack of references regarding theory in use in the SAP discussion, theory in use is a rather popular theme in management studies. Initially, Argyris and Schön (1974) focused their model on education and learning, but relatively soon thereafter, their studies considered organisation, strategy and management (see, e.g., Argyris, 1976, 1977; Argyris and Schön, 1978, 1983).

In addition to the further studies of Argyris and Schön, several other management researchers have focused their studies on the theory-in-use model and its single-loop and double-loop perspectives. These two perspectives have several other names in the studies of theory in use, such as lower-level vs. higher-level learning or monitoring vs. evaluation. Fiol and Lyles (1985) call these two ways of organisational learning 'lowerlevel learning' and 'higher-level learning'. The most important outcome of their literature 
review is that there is a distinction between organisational learning and organisational adaptation, which shows that change does not necessarily imply learning (Fiol and Lyles, 1985, p.803). Although they do not claim it exactly, they implicitly show that organisational learning is more similar to double-loop learning than to single-loop learning. Rowe (1996) calls these two main perspectives 'monitoring' (single-loop learning) and 'evaluation' (double-loop learning). According to Rowe (1996, p.22), the following statement of Warren Bennis describes the difference: "It is nice to do things right, but it is more important to do the right things".

Rowe (1996, p.17) noticed several important questions that depict the state of organisational learning, such as:

- Why do most management development programs espouse a philosophy that is rarely practised in the workplace?

- Why is so little thought given to who provides programs?

- Why does top management rarely partake of training and development?

- Why do managers want to learn new things by talking about old things?

- Should training and development critically consider organisational strategy?

- Why are programs rarely evaluated?

One outcome of Rowe (1996) is that organisations pay little attention to evaluating programs that they sponsor and fund. However, the quality of training programs is more important than the quantity of these programs. Furthermore, double-loop thinking makes us, according to Rowe (1996, p.23), more critical of everything and 'allows us to develop constructively'.

Rowe (1996) and Fiol and Lyles (1985) are good examples of the perspectives that follow relatively directly from the ideas of Argyris and Schön. However, there are also several further studies about learning organisation, which mention single-loop and double-loop learning, but are focused on several other perspectives. For example, Romme and Dillen (1997) map the emerging field of the learning organisation in a way in which the ideas of Argyris and Schön are only one part of the study. But the basic outcome of Romme and Dillen, the existing gap between individual and organisational learning, which is perhaps the biggest barrier in moving towards learning organisations, is not parallel to the main outcomes of Argyris and Schön.

Senge (1990) emphasises the role of a team's defensive routines as an obstacle to development and the success of the firm. Senge (1990) also stresses the importance of conflicts. Efficient teams and organisations have internal conflicts that are a source for learning. Too-agreeable, defensive teamwork without differing opinions is vulnerable to external changes. Actually, this viewpoint is parallel to the findings of Argyris and Schön regarding the fact that capable managers often fail to learn effectively in management teams because of defensive routines they created. Senge had several ideas about a learning organisation that were perhaps so tempting that there was afterward an influx of studies focusing on a learning organisation (see, e.g., Bui and Baruch, 2012; Mintzberg et al., 1998). 


\subsubsection{Strategy as practice}

SAP discussions are a relatively new phenomenon among management and strategic scholars. According to Carter et al. (2008, p.84), the first steps started towards a SAP perspective in February 2001, when a group of about 50 researchers convened at the European Institute for Advanced Studies in Management in Brussels and attended a workshop organised by Gerry Johnson, Leif Melin and Richard Whittington to discuss developments in strategy micro-processes. Later, they published a special issue of the Journal of Management Studies (Johnson et al., 2003). One specific characteristic of this scientific movement was the fact that at first the participants were mainly European.

Compared to the theory-in-use perspective, SAP discussions became institutionalised very quickly, and there was an active SAP group that emphasised micro-activities in strategising. Theory-in-use discussions started and developed at first only because of the work of Argyris and Schön. One example of the institutionalisation (or consolidation) of SAP was the publishing of another significant special issue of Human Relations in 2007 (Carter et al., 2008). In those days, the virtual community of SAP had more than 2000 members (Jarzabkowski et al., 2007, p.5).

According to Whittington (1996), the SAP perspective leans on the preceding 'process school' in which it is important "how organisations come first to recognise the need for strategic change and then actually to achieve it". However, in the SAP perspective, it is especially important how strategists actually strategise (Whittington, 1996, p.732). Hendry and Seidl (2003) noticed that, according to the literature, radical strategic change is especially difficult because of defensive routines, groupthink, strategic drift and the cultural web, which all refer to the self-reproducing nature of organisational practices and discourses. In addition, Hendry and Seidl (2003, p.177) also named typical methods of strategic change, such as unfreezing and refreezing (Lewin, 1947), second-order change (Watzlawick et al., 1974) and double-loop learning (Argyris and Schön, 1978). They (p.187) also see that it is important to construct arenas for critical reflection without any hierarchy, for example, in joint leisure activities, although successful episodes that lead to identifiable strategic changes may indeed be exceptional. Strategic change is a very problematic issue, and it is very important to follow the idea of double-loop learning regarding what actually happens in people's minds, although Luhmann's theory, for example, particularly emphasises social systems (Hendry and Seidl, 2003, p.177).

Although strategy research has been based on micro-economics traditions, due to the models of Michael Porter, for example, this has meant that research has focused on the macro-level of firms and markets. Therefore, Jarzabkowski et al. (2007, p.6) see that it is necessary to re-focus research on the actions and interactions of the strategy practitioner. This reinstatement of agency in strategic action is located within the wider 'practice turn' or 'linguistic turn'. Linguistics and discourses are an essential part of SAP research (see, e.g., Laine and Vaara, 2007). Recently, the 'narrative turn' has been mentioned in emphasising the importance of the micro-stories of managers in strategising and in strategy research. In these perspectives, there are praxis, practice, practitioners and texts in the interaction among them, which produce the content of strategising (Fenton and Langley, 2011).

The SAP perspective has several different manifestations. Typical for all these branches of SAP discussions is the aim of bringing human actors and their actions and interactions to the centre stage of strategy research (see, e.g., Jarzabkowski and Spee, 
2009, p.70). This makes possible the witnessing of a part of the 'practice turn' of social sciences. According to Whittington (2006), there are two traditional perspectives in social theory: those emphasising the importance of individuals and those emphasising the role of social forces. Whittington (2006, p.614) claims that the practice turn overcomes this dualism between 'individualism' and 'societism'. In addition, according to Whittington (2006, p.615), management research is increasingly engaging with the practice turn, drawing on it in fields of technology learning at work, institutional change, marketing and accounting. Thus, the practice turn (and SAP) is associated with learning and change - the important features of the learning school (emergent strategy) and the theory-in-use perspective.

Typically, the SAP perspective emphasises three themes: praxis, practitioners and practices - in other words, the practices of both organisations and their wider social fields and actual activity: praxis and actors, which are strategy's practitioners in this context. According to Whittington (2006, p.615), "social practices are followed in rough and ready ways, according to the exigencies of the situation". Jarzabkowski et al. (2007, p.11) define practices differently: they are 'cognitive, behavioural, procedural, discursive, motivational and physical practices that are combined, coordinated and adapted to construct practice.' Although there are different nuances in these three themes, they are widely accepted as the essential parts of strategising. Actually, strategising consists of praxis, practitioners and practices (see, e.g., Jarzabkowski et al., 2007).

\subsection{The comparison between theory in use and SAP}

In contemporary strategy research, it is typical to compare different perspectives, such as neo-institutional theory, with the SAP perspective (see, e.g., Suddaby et al., 2013). This study compares the features of SAP with the theory-in-use perspective. Furthermore, this study introduces knowledge management perspectives in the context of strategic change related to the theory-in-use and the SAP perspective.

As the literature review shows above, the theory-in-use and SAP perspective have several similarities and some differences. This sub-section discusses the most important similarities and differences between theory-in-use, SAP, and intra-organisational perspectives based on the literature review above.

Both theory in use and SAP emphasise the role of practices (Table 1). There are differences in these themes, however: in theory in use, the practices and routines of individuals and organisations are restrainers of learning and readiness during strategic change, but in SAP, they are important sources for emerging strategy making. Therefore, according to the theory-in-use theme, there is a need for double-loop learning, which also has effects on the theory in use of an organisation. In the SAP theme, strategy consists of practices, and the realised changes in strategies come from the practitioners of strategising, including the workers of an organisation. Single-loop learning considers only the ways of an organisation to achieve current targets, but will not question the relevance of these targets. Double-loop learning also contains critical thinking about the relevance of prevailing targets. Double-loop thinking is associated with critical thinking, which makes adherents more critical of everything, and this allows us to develop constructively (Rowe, 1996, p.23). Similarly, SAP questions the prevailing mainstream standpoint by sense-making strategising and is based on critical social constructionism (see, e.g., Laine, 2010) while focusing on doing the strategy. 
Table 1 Comparison between theory-in-use and strategy as practice perspectives with knowledge management reflections about strategic change

\begin{tabular}{|c|c|c|c|c|c|}
\hline Perspective & Main elements & $\begin{array}{l}\text { Relationship to } \\
\text { learning school/ } \\
\text { emergent } \\
\text { strategy }\end{array}$ & $\begin{array}{l}\text { Relationship to } \\
\text { 'practice turn' }\end{array}$ & $\begin{array}{l}\text { Relationship to } \\
\text { traditional } \\
\text { strategising }\end{array}$ & $\begin{array}{l}\text { The main message } \\
\text { or perspective } \\
\text { about strategic } \\
\text { change }\end{array}$ \\
\hline Theory-in-use & $\begin{array}{l}\text { Theory in use } \\
\text { (practical } \\
\text { actions), } \\
\text { espoused } \\
\text { theory; single- } \\
\text { loop and } \\
\text { double-loop } \\
\text { learning; } \\
\text { organisational } \\
\text { learning }\end{array}$ & $\begin{array}{l}\text { Single-loop and } \\
\text { double- loop } \\
\text { learning: theory } \\
\text { in use is } \\
\text { unchanged/ } \\
\text { changes. Often, } \\
\text { external } \\
\text { strategies are } \\
\text { not following } \\
\text { theory in use }\end{array}$ & $\begin{array}{l}\text { Practices and } \\
\text { routines are } \\
\text { often barriers } \\
\text { for learning. In } \\
\text { double-loop L. } \\
\text { also practices } \\
\text { change (theory } \\
\text { in use). } \\
\text { Emphasises } \\
\text { individual } \\
\text { practices }\end{array}$ & $\begin{array}{l}\text { Traditional } \\
\text { strategising is } \\
\text { based on single- } \\
\text { loop learning, } \\
\text { unchanged } \\
\text { routines/ } \\
\text { practices, and } \\
\text { prevailing theory } \\
\text { in use }\end{array}$ & $\begin{array}{l}\text { Strategists } \\
\text { underestimate the } \\
\text { role of learning in } \\
\text { strategic change. } \\
\text { Actual strategic } \\
\text { learning needs } \\
\text { double-loop } \\
\text { learning and } \\
\text { changes in theory- } \\
\text { in-use }\end{array}$ \\
\hline $\begin{array}{l}\text { Strategy as } \\
\text { practice (SAP) }\end{array}$ & $\begin{array}{l}\text { Praxis, } \\
\text { practitioners, } \\
\text { and practices }\end{array}$ & $\begin{array}{l}\text { Emergent } \\
\text { strategy is an } \\
\text { essential part of } \\
\text { SAP; learning is } \\
\text { a rarely } \\
\text { discussed theme }\end{array}$ & $\begin{array}{l}\text { SAP moves } \\
\text { between the } \\
\text { individual and } \\
\text { societal. The } \\
\text { study of } \\
\text { practices is a } \\
\text { source for } \\
\text { strategising } \\
\text { research }\end{array}$ & $\begin{array}{l}\text { Traditional } \\
\text { strategising } \\
\text { underestimates } \\
\text { the role of } \\
\text { practices and } \\
\text { practitioners }\end{array}$ & $\begin{array}{l}\text { Strategic change is } \\
\text { emergent, not so } \\
\text { often planned, and } \\
\text { sometimes starting } \\
\text { from the bottom up }\end{array}$ \\
\hline $\begin{array}{l}\text { Knowledge } \\
\text { management in } \\
\text { strategic change }\end{array}$ & $\begin{array}{l}\text { Knowledge- } \\
\text { based resources } \\
\text { and routines }\end{array}$ & $\begin{array}{l}\text { Organisational } \\
\text { learning in the } \\
\text { context of KM }\end{array}$ & $\begin{array}{l}\text { In the forms of } \\
\text { routines and } \\
\text { competencies }\end{array}$ & $\begin{array}{l}\text { Emphasises } \\
\text { RBV and a } \\
\text { (sustainable) } \\
\text { competitive } \\
\text { advantage }\end{array}$ & $\begin{array}{l}\text { Strategic change is } \\
\text { knowledge-based, } \\
\text { having reflections } \\
\text { on human } \\
\text { resources and RBV }\end{array}$ \\
\hline
\end{tabular}

For the sake of comparison, this section also introduced the perspectives of knowledge management in the context of strategic change. Table 1 shows the KM perspective regarding strategic change fits well with the theory-in-use perspective and the SAP perspective. Although these two are separate discussions, they consider issues that are also typical for knowledge management discussions. Often, the KM perspective emphasises RBV and (sustainable) competitive advantage themes associated with strategic change (see, e.g., Bloodgood and Salisbury, 2001; Ordóñes de Pablos, 2004; Monteiro and Pianna, 2012; Afiouni, 2013), which in fact seems to distinguish the KM perspective from SAP and theory-in-use perspectives in the context of strategic change.

\section{Research methods}

\subsection{The case study material}

The case study material consists of a web search (on 11 July 2013) with the following index words: comments 'strategic change' (with quotation marks). The search engine used was Google. The search output was 359,000 files. The first 100 files were picked up in this analysis. The initial aim was to get as many comments as possible for the 
considered blogs; therefore, 'comments' was included in the search line. Because one target was to get hints for SAP and theory-in-use, more informal comments were a welcome part of the empirical material. The research material included 73 blogs; 27 files were unsuitable for analysis. Seven of them consisted of videos, five of them were books or book advertisements, five were scientific articles (or their announcements or abstracts), one file was the definition of 'strategic change' and two of them were too short, consisting only of a couple of rows of text. There were 4 files (or their content) included twice among the population of 100 files. Furthermore, two files were diagrams, and one file was a course announcement. The analysis focused on the blogs about strategic change (and their rare comments). The blogs were mostly written by consultants or journalists. Videos were excluded from the analysis because of their changeable quality and length (no voice was available, or they were long or consisting of diagrams). Scientific articles were not included in the research population because of the aim to find practical attitudes about strategic change, not the ready scientific discussions. Thus, the analysis is based on the written materials about strategic change that are mainly provided by the consultants.

The decision to use blogs and comments from the web is based on the fact that both blogs and their comments are an important media channel in contemporary global society. Persons and enterprises are more familiar with expressing their thoughts because of a 'direct linkage to the world' via the web. In this sense, there has been a 'cultural turn' in ways of expression as a part of postmodernism (see, e.g., Rojek and Turner, 2000).

One surprising finding was that, although there is a specific space for comments in blogs, only 14 blogs out of 74 get any comments at all, and these comments were mostly very short. Some blogs get several comments, and for this reason, the total number of analysed comments is 209 . Because of these characteristics of comments, the main focus is on the initial text material based on blogs (Table 2).

\subsection{About the study methods}

In addition to the literature review about theory in use, SAP and their comparison, this study also has an empirical analysis of web-based blogs and comments. Actually, this study follows the 'narrative turn' of strategic research, which emphasises the importance of micro-stories as a resource for strategising (Fenton and Langley, 2011). The empirical part of this study is based on the method of critical discourse analysis. One important aim of the analysis is to map the underlying attitudes of consultants and consulting firms about strategic change and strategising. Because the aim is to find, for example, theoryin-use attitudes from the ostensibly officially expressed sentences of blogs, the analysis has to be critical: most of the expressions in blogs reveal pieces of exposed theory rather than theory in use. While studying the blogs of consultants from the theory-in-use perspective, we also possibly get material for the needs of the study for the SAP discussions and their manifestations in the external blogs and their comments. According to Mautner (2005), web-based materials are an underestimated source for critical discourse analysis, having potential analytic contemporary research. 
Table 2 Some details about the case study material

\begin{tabular}{lc}
\hline Research units (blogs) in analysis & 73 \\
Number of blogs having comments & 14 \\
Total number of comments & 209 \\
The cases excluded from the analysis, reasons: & \\
Video & 7 \\
Book & 5 \\
Article & 5 \\
Definition & 1 \\
Too short & 2 \\
Double & 4 \\
Diagram & 2 \\
Course & 1 \\
Total, out of the analysis & 27 \\
All blogs & 100 \\
\hline
\end{tabular}

Critical discourse analysis is a typical method in studies of social sciences. Critical discourse analysis is not any fixed method, but has several different manifestations. Critical discourse analysis concerns itself with relations of power and inequality in language (Blommaert and Bulcaen, 2000). According to Fairclough et al. (2011, p.357), critical discourse analysis is a "problem-oriented interdisciplinary research movement, subsuming a variety of approaches, each with different theoretical models, research methods and agendas. What unites them is a shared interest in the semiotic dimensions of power, injustice, abuse, and political-economic or cultural change in society". In critical discourse analysis, discourse practices help sustain and reproduce the social status quo, but also might help transform it (Fairclough et al., 2011).

This study is focused on the discourse practices of consultants, whether they reproduce the prevailing mainstream perspectives about strategy and strategic change or provide new practical-based perspectives about strategy. One interesting detail is the possible differences and similarities between the espoused theory and theory in use in the contents of these consultants' blogs.

\section{Outcomes of the empirical analysis}

The content of the blogs and their comments in the case study material are extremely changeable. For example, the length of the blogs varies from a couple of rows to tens of pages containing the stories and/or manifests about strategic change and strategic change management. Most of the writers are consultants or CEOs of the consultant firms.

The material involves four main discourses: change resistance, top-down change, learning and finally, inter-organisational coopetition. For learning, there was also a 'trial-and-error' sub-discourse. The writers consider the themes of theory in use, practices associated with strategising, coopetition (mainly implicitly), adaptation and learning. 


\subsection{Change resistance}

The term 'resistance' was mentioned 35 times in the case material. Resistance was considered in the context of learning and/or adaptation in the sense of theory in use, in the context of managerial top-down attitudes and when comparing texts between these two alternatives.

The following comment actually reveals that social collaboration, like groups, is a typical tool to discourage change resistance; some of the individuals are against social collaboration in them as a strategic tool. This comment includes both collaborative and competitive elements reflecting coopetition perspectives (see, e.g., Brandenburger and Nalebuff, 1996).

"One of the things Change also does is, it allows for the underlying structure (support, rules of conduct, etc.) necessary for truly collaborative groups to be put in place. Groups, as Hackman from Harvard will attest, are one of the new business darlings. Add in the new (or slightly old, depending on your perspective) focus on social collaboration, and you have yet one more reason for an obsession with Change." (97, C)

Change resistance is a subject that cuts a dash and provides phrases among consultants. Below are some short examples:

"People don't resist change. They resist being told to change or being changed by someone else." (Haudan, 2013)

"There are always two parties - the party of the past and the party of the future, the establishment and the movement." (R.W. Emerson via Hamel, 1996, p.74)

"People tend not to change their way of doing things unless they have a compelling reason to do so." (unknown)

These examples show that change resistance might be based on personal characteristics and/or a lack of information, participation and empowerment in an organisation. In the following pieces of text, change resistance is also based on this need, and furthermore, it has been considered as emphasising individual and/or a constructive perspective resembling some nuances associated with SAP and theory-in-use themes.

"Participation and involvement: A strategy needs to be devised to facilitate the participation and the involvement of the stakeholders in the change process. This gives them motivation, and a sense of involvement makes them feel part of the change to which they don't try to become a resistance." (54)

"People in business are not as obvious as schoolchildren, but you can see the same kind of incremental resistance. A typical example is change meetings, where they all turn up for the first one, but then a bit at a time they have 'more important' things until you end up chairing a mostly empty room. One of the main activities of the change manager is chasing. Relentlessly follow up with people who miss things or have commitments. Get senior managers to help by first making clear imperative statements, and then follow up with real corrective action." (18)

"Resistance to change is a part of the change process. It is something which can have both positive as well negative impacts on the organisation. Kotter and Schlesinger (1979) explained the importance of strategy to handle the resistance in the organisation." (45) 
"Yet, even today, organizations don't understand how important it is to bring staff along on the exploration journey rather than presenting them with already formulated change decisions and processes. Then, when they balk, preferring the old, or just not having had time to think about the new, they are labeled 'resistors'. Their next question to me is about how to deal with employee resistance. I have a standard answer; don't create it in the first place." (31)

Most of these citations implicitly emphasise the importance of the whole organisation in the strategic change process. Furthermore, these examples are more suitable for double-loop learning compared to single-loop learning: the members of organisations are empowered to discuss and even decide the aims of the organisation. Strategic change has to be widely accepted, which is possible if different levels of the organisation are involved in the planning processes of strategic change. These citations are similarly suitable for the theme of SAP and theory in use. This finding also implies the general similarities between the theory-in-use and SAP themes. Throughout the texts about change resistance, there was a collaborative tendency that emphasises the importance of participation.

\subsection{Top-down change}

A frequently heard phrase regarding traditional mainstream management and strategy making is 'top-down management'. Top-down management presents the control of single-loop learning. This perspective is also ordinary among consultants' expressions. However, when the term 'top-down' is used precisely, the consultants provided completing perspectives for top-down management and the strategy process:

"The pilot program of reengineering an Army installation that I participated in
as the senior military planner featured some of the elements of ISC, and in
those areas, the plan was much more successful than when we applied
traditional means. To the extent that we consider transitions in implementation,
human factors, and incorporated stakeholders from every echelon, we were
successful. When we tried to implement a top-down, from-a-distance strategic
vision, we suffered the usual problems of traditional planning." (22)

"Kotter advocates a second, parallel organizational 'Operating System' for implementing strategic changes in a company. He suggests this approach would be much more effective than the traditional top-down hierarchical 'operating system' for implementing change. This second, parallel 'Operating System' is based on a network organization of highly competent and passionate volunteers from within the company who represent all functions of the organization. This group of employees will focus on designing and implementing the strategic changes, while the traditional 'operating system' will continue to run the company until the changes are fully 'institutionalized'." (94)

"Most changes are delivered top down in terms of broad direction with little detail on exactly what a person needs to do to contribute. Sometimes, it is unclear if a person needs to do anything or even if they are affected." (63)

"Amazon is rather unique in that it has changed its business model in the absence of a performance crisis. Usually, major strategic shifts are driven by a financial meltdown, or years of substandard returns. As I've said on numerous occasions, deep change in big companies usually happens the same way it happens in poorly governed dictatorships - infrequently, belated, and convulsively; and for the same reason - a top-down authority structure frustrates bottom-up change. All too often, by the time an issue gets big enough to attract the CEO's attention, whether an opportunity or a threat, it's too late to 


\begin{abstract}
do anything but react. A case in point: By the time Google's top brass roused themselves to do something serious about social media, Facebook had already built a nearly insurmountable lead. In my experience, the vast majority of corporate 'change' programs are 'catch-up' programs." (27)
\end{abstract}

The latter comment (27) shows the importance of participation in strategy making. In order to have strategic change, we have to get a wide range of members participating instead of a couple of gate-keepers of the strategy group, which might be directed towards a 'catch-up' program. All these citations express the importance of participation in strategic change. However, it is possible that the expressed negative attitudes of consultants towards 'top-down' management will not mean an actual overall theoryin-use perspective, but the fact that the explicit resistance of top-down management is in the role of espoused theory. These comments suit well the basic ideas of SAP while emphasising the importance of dialogue and social collaboration. The competitive element and therefore coopetitive element, however, are minor among these text examples.

But there were some comments of consultants that have an underlying perspective associated with top-down management and strategic change:

\begin{abstract}
"After the needs of an organisation are established in the strategic focus, we move on to the strategic plan, which involves an integrated effort from the top down with performance measures, process improvement goals, leadership development, strategic planning, and governance development. It is never just a one-day process as you keenly noted ... way too fast!" $(54, \mathrm{C})$

"As a leader, you need to establish credibility and a track record of effective decision making, so that there is trust in your ability to figure out what is necessary to bring the organisation through. If the organisation does not have such leaders, there is a need for an overhaul at the top." (11)
\end{abstract}

Both of these citations are emphasising the role of management or leaders. Actually, they are following mainstream attitudes about the importance of leadership in the form of top-down management. However, the majority of the expressions associated with the top-down perspective provide complementary perspectives for top-down management. This is also found in the contemporary form of discourse, which questions top-down management in the context of strategic change, confirming the found collaborativeintensive perspective among the web media texts of consultants.

\title{
4.3 Learning
}

The literature review showed the importance of learning in the context of strategic change literature and discussions especially among emergent strategy, theory-in-use and SAP themes. Furthermore, learning was one of the main themes in the studied media texts. The keyword 'learning' gets 49 hits among the case material. Practically all blogs and comments were related positively to learning. However, there were various underlying perspectives about learning. For example, there were comments about the individual personal learning (of strategists):

"I seem to be able to control my own mindset and adapt relatively easily ... I think I'm lucky that way - keeping the open mind, knowing things will change and being 'ready' even if one isn't ... I'm very pro-active ... sometimes too much for some people - but I keep a positive outlook and love learning." (Comment 18) 
"Inevitably, informal non-conformist interactions provide better options, grassroots upwards. In learning to 'mange and lead' by walking around, the leader must remain in constant touch with ground realities. His office needs no curtains and doors, and he should be seen more on the shop floor or the marketplace - in touch with his people, products and the markets. This, without courting populist gimmicks, can transmit the intent, integrity and honesty of purpose of the leader to the environment. It will make him approachable and spur dialogue for change a change for the better." (11)

One interesting topic of discussions is focused on trial and error - sub-discourse, which is an essential part of double-loop learning (Argyris, 1980, p.291).

"There have been lots of posts about adaptability and the importance of learning from mistakes and things that go wrong. While lots of organisations talk about this, I'm not sure how many actively follow through. One interesting example I have recently come across is the Office of eDiplomacy at the US State Department, who have set up a shared online platform called 'Failfaire,' which allows individuals to talk about failures and things that have gone wrong and share the lessons learnt from these. So, going forward with failure together." $(27 \mathrm{C} 1)$

"When I think about adaptation, I think about Jean Piaget, the famous child psychologist who became very interested in children's wrong answers to intelligence tests. Piaget worked with Binet on the IQ test, but Piaget was less interested in a static score and how much you knew, he was more interested in how you went about knowing and adapting to your world." (27 C2)

"Organisations look up to the leadership for a large number of things. The foremost is the leader's supportive role in providing the overarching vision, coherence and capacity to operate seamlessly through the chaos of the work and marketplace. This translates into leadership's extreme tolerance for ambiguity and capacity to absorb Ristakes (Risk plus Mistakes) in the environment around them, both in and out of the organization. That develops faith, which simplifies the leader-led equation where teams continue to surprise the leaders by their initiative and proactive adaptation to change." (11)

These attitudes above are suitable both for the theory-in-use with double-loop learning and SAP themes. According to these comments and comments below, strategic adaptation is linked with learning:

"Strategic adaptability begins with an insatiable appetite for knowing and learning and a full appreciation that the more you know, the more there is to know. Strategic adaptability then would be a plan (or approach) for questioning everything, challenging assumptions and trying to see what we currently don't see. Such an approach would require deliberate non-conformance for the purpose of discovery." (27 C3)

"When I asked 45 CEOs what they would have done differently in strategy execution, they all responded that they would have linked it to pay for performance sooner because it created a powerful motivational force for employees. Most of them also indicated that they would have started monthly strategy review meetings emphasizing learning and improvement rather than finger-pointing earlier in the process." (64)

Generally, the empirical material shows the importance of the practice turn associated with strategic change. The practice turn is true at least on the level of espoused theory: most of the blogs and comments take into the account the roles of the workers and, in addition to the CEO, the roles of the other managers of the organisation. 
Across the media texts and their discourses above, the positive attitudes towards collaboration were evident. However, because the main paradigm of the society and economy is based on competition, the general underlying tendency among the discussions and attitudes of consultants contains tension between competition and cooperation, that is, on coopetition. Coopetition is simultaneous cooperation between competing units, firms, organisations and networks (see, e.g., Brandenburger and Nalebuff, 1996).

On the micro-level, coopetition is known as an 'intra-organisational coopetition' or 'coopetition within a firm' (see, e.g., Tsai, 2002). The collaborative comments about strategic change in the case study material are focused on relationships among the units or workers of the same organisation, confirming the importance of intra-organisational collaboration and coopetition. Because of the arising importance of coopetition, this study considers one more discussion, intra-organisational coopetition among the media texts and generally as a research perspective. This decision to emphasise the coopetition theme is based on the empirical findings of this study. Thus, this study is also following 'emergent research strategy' (see, e.g., Meynell, 2005).

\title{
4.4 Intra-organisational coopetition
}

The case material does not include the exact terms 'coopetition' or 'co-opetition', but dozens of expressions have 'competition', 'compete', 'collaboration' or 'cooperation' in their contexts, which mean coopetitive activities. This sub-section introduces some examples of these citations having a coopetitive tendency.

\begin{abstract}
"Nokia counts on all the skilled or unskilled staff for the organization hires to work for them. Nokia does hire highly skilled staff due to the nature of technology work, provides them with training to keep them updated, and creates opportunities for program developers who can work from home to compete in a competition to win prices and even offer them jobs. In this time of recession and economic downturn, even Nokia is looking to cut costs by making their surplus staff redundant." (9)
\end{abstract}

The citation above describes the situation of (professional) consumer coopetition (Walley, 2007), in which active customers are competing with each other in order to develop better solutions for Nokia. Because this simultaneous competition and cooperation is restricted to one company, it is a case of intra-organisational coopetition. Also, this example considers a case of innovative learning: the participants are learning and developing their skills. Furthermore, the company is gaining from this platform by developing its products. If the products of the company really change, this is a matter of double-loop learning. However, the strategy of the firm will not change significantly because of this crowdsourcing manoeuvre (see, e.g., Rusko, 2012). Knowledge sharing seems to be an important part of intra-organisational coopetition. In the citations below, the first one is more likely inter-organisational than intra-organisational coopetition, also fulfilling the features of crowdsourcing.

"We are starting to use the Local Government Association Knowledge Hub, which is a platform specifically created for the Public Sector. We share our lessons learned and our successes with others across the Public Sector. It is a free collaboration platform that allow you to set up your own discussion group." $(27, \mathrm{C})$ 
"I imagine an adaptive organization would have a very flat structure. People would be recognized for their knowledge and skills and not titles, where teams form organically to achieve a specific outcome that furthers the (organization's) purpose/goals. Everyone would clearly understand the purpose and be personally committed to achieving the collective goals, which in turn would fulfill their personal goals. They would accept full ownership for understanding their environment (anything that influences or affects their work, customers, team members, markets, industry suppliers etc.). People would be engaged in (what I call) Think Out Loud sessions - where random people come together to 'think' for the purpose of understanding, clarifying or discovering. They would have several experiments working and high customer satisfaction, highly engaged team members, many new ideas and innovative solutions. It would be an organization fueled by discovery, not competition." $(27, \mathrm{C})$

These comments, especially the latter one, emphasise intra-organisational coopetition, or more strictly, intra-organisational cooperation, because they are a kind of apology for cooperation instead of competition. However, the underlying feature of this comment is that there often is competition in the intra-organisational teamwork, and this coopetition has an unintentional feature. This comment also considers learning, actually double-loop learning. Furthermore, this touches on strategy making and its practices, allowing emergent innovations and strategies. In this sense, this is following the ideas of SAP: practitioners, practices and praxis are all involved in this description. These same characteristics are also important below:

"For example, looking at examples of successful start-up organisations, or renowned innovative brands (e.g., Gore), it is clear that some working environments and conditions lend themselves much better to spontaneity and innovation than others. Co-location in an open plan space contributes to ease of communication between the key roles, as do flatter structures that take out layers of decision-making. Even the more relaxed conditions contributed by having a radio on may well stimulate the kind of conversations and ideas that spark different ways of thinking. Spaces and places to play around with ideas writing or drawing on flip charts and whiteboards and whitewalls rather than the stiff rules that forbid posters, stickies on the paintwork, and working in virtual silence etc. These kind of rules send a clear signal that order and image, individual achievement rather than collaboration, are more highly valued than spontaneity and the right level of disorder that stimulates, rather than stifles ideas early in their infancy." (36)

This citation above shows the importance of place and co-location in innovative projects. Furthermore, this comment, again, is an apology for collaboration in innovative projects instead of individual top-down management-based competition. This example also shows the links between three themes: intra-organisational coopetition, learning associated with theory in use and SAP. This example reveals the importance of social construction and interactions, the features typical for SAP, while developing innovative strategies of the company.

The role of intra-organisational coopetitive thinking is remarkably associated with innovative teamwork during innovation-based strategy making. However, coopetition appears more like the forms of cooperation-based coopetition as competition-based coopetition. Consultants and bloggers of change management seem to emphasise intraorganisational collaboration instead of competition. 


\section{Discussion}

The competition tendency or paradigm can be found throughout business and consultant work (see, e.g., Rosenau, 2003). However, the media texts and their revealed discourses proved that, in the context of strategic change, there is a collaborative emphasis. In addition, the ideas of Senge (1990) about the need for internal constructive conflicts during collaborative teamwork to manage external threats suit the coopetition theme well. Because of the importance of especially intra-organisational coopetition, this section concentrates on this theme.

Generally, individuals and their networks are the power and the actors for the microlevel, meso-level and macro-level types of coopetition (see, e.g., Bengtsson and Kock, 2000). According to Tsai (2002), intra-organisational coopetition is based on the social network perspective of organisational coordination. The empirical analysis found the significance of social networks and teams in the strategic change process, though some of these networks were web based.

Intra-organisational coopetition has several alternative forms. Luo (2004; see also Hong and Snell, 2013), for example, considers coopetition within a multi-unit company. Although the role of individuals is important in the characteristics of coopetition, the main considerations of coopetition do not concentrate on simultaneous cooperation and competition between individuals, except consumer coopetition, which has been introduced by Walley (2007). Generally, intra-organisational coopetition is especially possible if there are several units in the company and/or the company is a multinational enterprise, having geographically dispersed subunits (see, e.g., Luo, 2004).

Tsai (2002, p.179) investigates intra-organisational coopetition associated with the effectiveness of coordination mechanisms on knowledge sharing in intra-organisational networks that consist of both collaborative and competitive ties among organisational units: "organisational units compete with each other to gain resources and competences that are embedded in intraorganisational networks. These units may serve similar markets, and their rewards and status may depend on how they perform relative to other units in the same organisation". Also, in the case study material, innovation teams and knowledge sharing were relevant elements of intra-organisational coopetition. Typically, although the workers and organisational units belong to the same multi-unit company, there is underlying competition between the units and workers.

In the introduction, this study mentioned the relationship between three parts: theory in use, emergent strategy (learning school) and SAP. The assumption was that these themes have links with each other, for example, because of the practice turn of strategic management. Furthermore, during this study, the importance of collaboration and coopetition has been raised. Therefore, it is reasonable to take the coopetition theme into account in the context of the practice turn.

Intra-organisational coopetition occurs in the sample of strategy change discussions in the form of cooperation-based coopetition, especially in the context of innovative strategy making and R\&D collaboration. In these cases, media texts also contain connections between intra-organisational coopetition and theory in use and SAP (Figure 1). 
Figure 1 Underlying perspectives for the practice turn in strategic management, strategy as practice, and intra-organisational coopetition (see online version for colours)

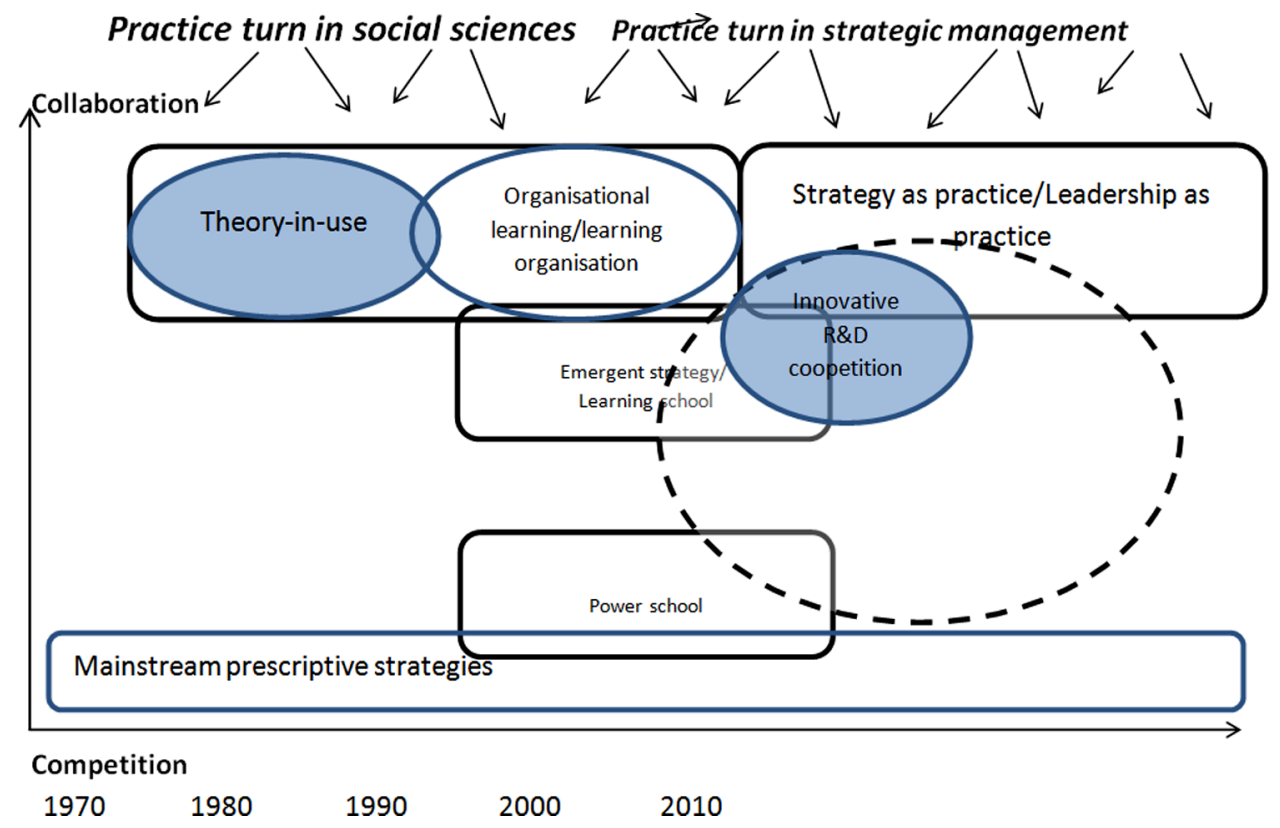

In addition, the general practice turn in social sciences has important ramifications for the development of the SAP theme and more generally for the practice turn in strategic management. It is noteworthy that SAP has met completing themes, such as leadership as practice in the field of management studies (see Carroll et al., 2008). There is an obvious chronological order between these themes, which is depicted in Figure 1. However, all of these discussions are still important branches of discussions in contemporary management studies.

One aim of this study was to implement critical discourse analysis. The results were practically based on qualitative analysis generally and on the combination of (critical) discourse analysis and content analysis. However, the results are often based on literal expressions in the material. However, for example, the term 'coopetition' was not directly used in the media texts. The texts with underlying coopetition mainly consider different forms of collaborative actions and activities that are often associated with single-loop or double-loop learning, having a minor role for competitive expressions. Simultaneous intra-organisational collaborative and competitive expressions were mostly associated with innovations, for instance, with coopetitive crowdsourcing. We arrived closest to the theory-in-use perspective by studying the content of very informal comments. This outcome (the changed research process) is a typical part of qualitative research strategy. Actually, the fact is that analysis is often based on literal expressions instead of implicit expressions, which will possibly strengthen the contents of the outcome: the role of the subjective interpretations of results is decreased.

Furthermore, this analysis revealed the division between learning and managing. The main research themes, such as SAP, intra-organisational coopetition and naturally theory-in-use discourses occurred in the context of various forms of learning. Similarly, trial-and-error discourse emphasises learning and a cooperation feature similar to SAP, 
theory in use and mainly the intra-organisational coopetition themes. Surprisingly, top-down discourses (which actually emphasise the importance of a bottom-up direction in strategy making) would be located in the same box among the case study material. Thus, all these themes/discourses are located mainly in the cooperation-learning box in Figure 2.

In addition, the case study material contains several management tools, such as political, economic, social/cultural, technical/technological (PEST)-analysis, enterprise resource planning (ERP), customer relationship management (CRM) and the competitive advantage perspective. Actually, the competitive advantage perspective is related to KM in the context of strategic change - and organisational learning (Ordóñes de Pablos, 2004; Monteiro and Pianna, 2012; Afiouni, 2013), which means that a competitive advantage, in this sense, has connections with learning. These themes are mainly focused in the joint competition-managing perspective, excluding PEST analysis, which is based on the important stakeholder relationship.

Figure 2 The positions of theory-in-use, SAP, and intra-organisational coopetition among the combination of learning-managing and cooperation-competition dimensions

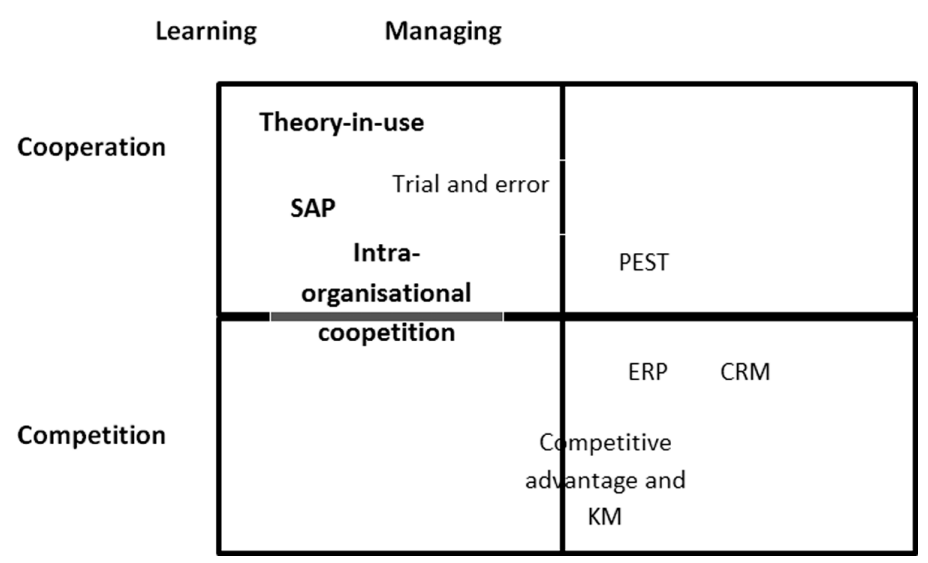

\section{Conclusions}

Learning, even strategic change, proved to be collaborative terms in this case study material. Thus, there is a tendency towards value co-creation rather than value appreciation among the blogs and comments of consultants. We live in a competition society, in which competitive elements are everywhere. This means that if we have significant collaborative activities, we also have in these cases a (paradoxical) tension between competition and cooperation (see, e.g., Jarzabkowski et al., 2013), in other words, coopetition. In the case of strategic change, the focus is on intra-organisational relationships, which are based on the relationships between different parts and individuals of an organisation. In addition, coopetition is mainly in the form of intra-organisational coopetition.

We live in a 'Facebook society' in which micro-stories in the forms of blogs and chats reveal even the theory-in-use perspectives of consultants and strategists. Due to importance of narratives in the forms of micro-stories, this study also participates in the discussions of the narrative turn in strategy research (Fenton and Langley, 2011). 
Underlying intra-organisational coopetition, expressions are mainly connected to learning, R\&D development and innovative strategy making. Still, the underlying paradigm of management is based on competition. However, the general tendency in the media texts of consultants was based on collaboration. Thus, there is either an unintentional or intentional coopetition attitude (see, e.g., Kylänen and Rusko, 2011) throughout all the case study material. The emphasis is deviating between competitionbased to collaboration-based coopetition, mainly the last one. In these cases, coopetition has links to theory-in-use and SAP themes. It seems that contemporary consultants use mainly collaborative and bottom-up perspectives in their web texts about strategic change. However, the analysis revealed that strategic change discussions of SAP and of theory in use have links to KM discussions, which emphasise the importance of knowledge-based resources, RBV and a sustainable competitive advantage. Similar to SAP and theory in use, KM also emphasises (organisational) learning as one of the relevant elements of strategic change. It might be possible even to restructure strategic change discussions so that $\mathrm{KM}$ is the starting point of the analysis, covering at least partly both SAP and theory-in-use perspectives regarding strategic change.

The empirical material of this study supports the interpretation about the importance of learning in strategic change. Learning connects not only theory-in-use and SAP themes, but also intra-organisation coopetition, though partially. Learning and, for example, the trial-and-error sub-discourse are also the linking perspectives between the theory-in-use and SAP themes. In addition, change resistance was an important expression in the blogs of the consultants, also having slight links to coopetitive attitudes. It is noteworthy that change resistance and trial-and-error are essential themes in the theory-in-use perspective. Change resistance and trial-and-error are also the power of the SAP and emergent strategy perspectives, which emphasise the details associated with doing strategy instead of top-down-based planning. Thus, this study shows that consultants are using the important expressions both for the SAP and theory-in-use themes, such as learning, trial-and error and change resistance, while generating and implementing the practice turn of strategic change. Furthermore, for example, the expression 'top-down management' has been in the case material mainly in the context of the examples that serve as a warning.

\subsection{Implications for theory and practice}

Organisational learning was an important part of this practice turn in the case study material: in addition to (change) resistance, learning was one of the most popular expressions among the blogs and comments in the material. Learning is also the perspective that links theory in use, SAP and sometimes coopetitive themes. Coopetitive expressions in the sample material were associated with learning and teamwork. However, the expression 'learning' has more connections to the theory-in-use and SAP themes compared to the coopetition theme. Emergence is an important part of the learning school, the school closest to SAP among the 10 schools of Mintzberg et al. (1998). Change resistance is an essential theme in the theory-in-use perspective (Argyris and Schön, 1974). Change resistance is also the power of SAP, which emphasised the details associated with doing strategy instead of top-down-based planning. Thus, this study shows that consultants are using expressions important both for the SAP and theory-in-use themes, such as learning, top-down and change resistance, while generating and implementing the practice turn of strategic change. 
The practical contributions of this study are based on case study material about consultants' attitudes towards strategic change. They see top-down management as having several problems that cause change resistance. In the situations of strategic change, there is a need to empower the different levels of an organisation. Important questions are: Why is this strategic change so necessary? What can we all do? and How we can do these changes? The right information is necessary, and the decisions have to be made with several participants from different levels of the organisation. These themes were the most evident among the case materials, which are based on media texts on the web.

\subsection{Limitations and future research}

There are some limitations associated with this study and its outcomes. These limitations are based on case study material. Although blogs and their comments are one of the most important drivers of information in the contemporary world of media, they are written texts. This fact has reflections in the content of the case study material. Written material is suitable mainly for the studies of espoused theory. However, one of the research themes is focused on theory in use. Despite this, comments on the blogs were written in colloquial language, which might also enable the discovery of theory-in-use reflections.

One of the outcomes of this study is that management theories are overlapping. Particularly theory in use and SAP have several joint perspectives, to say nothing of the fact that KM has also similar viewpoints with SAP and theory in use in the context of strategic change. There are varied perspectives of theory-in-use, coopetition and SAP themes. But many other management perspectives associated with strategic change and learning - such as KM, institutional theory and its implications on psychological ownership or intrapreneurship - have been passed over in this study. However, this means an enormous opportunity for further study: how do these concepts consider strategic change and how are these themes linked with each other and with SAP and theory in use in the context of strategic change and learning?

\section{References}

Achtenhagen, L., Melin, L. and Naldi, L. (2013) 'eDynamics of business models-strategizing, critical capabilities and activities for sustained value creation', Long Range Planning, Vol. 46, No. 6, pp.427-442.

Afiouni, F. (2013) 'Human capital management: a new name for HRM?', International Journal of Learning and Intellectual Capital, Vol. 10, No. 1, pp.18-34.

Argyris, C. (1976) 'Single-loop and double-loop models in research on decision making'. Administrative Science Quarterly, Vol. 21, No. 3, pp.363-375.

Argyris, C. (1977) 'Leadership, learning, and changing the status quo', Organizational Dynamics, Vol. 4, No. 3, pp.29-43.

Argyris, C. (1980) 'Some limitations of the case method: experiences in a management development program', Academy of Management Review, Vol. 5, No. 2, pp.291-298.

Argyris, C. (1991) 'Teaching smart people how to learn', Harvard Business Review, Vol. 69, No. 3, pp.99-109.

Argyris, C. and Schön, D.A. (1974) Theory in Practice: Increasing Professional Effectiveness, Jolley-Bass, Oxford. 
Argyris, C. and Schön, D.A. (1978) Organizational Learning: A Theory of Action Approach, Addison Wesley, Reading, MA.

Argyris, C. and Schön, D.A. (1983) 'Editorial', Journal of Management Studies, Vol. 20, No. 1, pp.3-5.

Argyris, C. and Schön, D.A. (1996) Organizational Learning II: Theory, Method, and Practice, Addison-Wesley, San Francisco, CA.

Bengtsson, M. and Kock, S. (2000) 'Coopetition' in business networks - to cooperate and compete simultaneously’, Industrial Marketing Management, Vol. 29, No. 5, pp.411-426.

Blommaert, J. and Bulcaen, C. (2000) 'Critical discourse analysis', Annual Review of Anthropology, Vol. 29, pp.447-466.

Bloodgood, J.M. and Salisbury, W.D. (2001) 'Understanding the influence of organizational change strategies on information technology and knowledge management strategies', Decision Support Systems, Vol. 31, No. 1, pp.55-69.

Brandenburger, A. and Nalebuff, B. (1996) Co-opetition, Doubleday, New York.

Bui, H.T. and Baruch, Y. (2012) 'Learning organizations in higher education: an empirical evaluation within an international context', Management Learning, Vol. 43, No. 5, pp.515-544.

Carroll, B., Levy, L. and Richmond, D. (2008) 'Leadership as practice: challenging the competency paradigm', Leadership, Vol. 4, No. 4, pp.363-379.

Carter, C., Clegg, S.R. and Kornberger, M. (2008) 'Strategy as practice', Strategic Organization, Vol. 6, No. 1, pp.83-99.

Chia, R. and MacKay, B. (2007) 'Post-processual challenges for the emerging strategy-as-practice perspective: discovering strategy in the logic of practice', Human Relations, Vol. 60, No. 1, pp.217-242.

Dalsgaard, S. (2008) 'Facework on Facebook: the presentation of self in virtual life and its role in the US elections', Anthropology Today, Vol. 24, No. 6, pp.8-12.

Fairclough, N. Mulderrig, J. and Wodak, R. (2011) 'Critical discourse analysis', in Van Dijk, T.A. (Ed.): Discourse Studies: A Multidisciplinary Introduction, Sage, London, pp.357-378.

Fenton, C. and Langley, A. (2011) 'Strategy as practice and the narrative turn', Organization Studies, Vol. 32, No. 9, pp.1171-1196.

Fiol, C.M. and Lyles, M.A. (1985) 'Organizational learning', Academy of Management Review, Vol. 10, No. 4, pp.803-813.

Hällgren, M. and Lindahl, M. (2012) 'How do you do? On situating old project sites through practice-based studies', International Journal of Managing Projects in Business, Vol. 5, No. 3, pp.335-344.

Hamel, G. (1996) 'Strategy as revolution', Harvard Business Review, Vol. 74, No. 4, pp.69-82.

Haudan, J. (2013) Duress vs Success in Engaging People to Achieve Strategic Change, Switchandshift, Accessed 30 March, 2015, from http://switchandshift.com/duress-vs-successin-engaging-people-to-achieve-strategic-change

Hendry, J. and Seidl, D. (2003) 'The structure and significance of strategic episodes: social systems theory and the routine practices of strategic change', Journal of Management Studies, Vol. 40, No. 1, pp.175-196.

Hong, J.F.L. and Snell, R.S. (2013) 'Developing new capabilities across a supplier network through boundary crossing: a case study of a china-based MNC subsidiary and its local suppliers', Organization Studies, Vol. 34, No. 3, pp.377-406.

Jarzabkowski, P. (2005) Strategy as Practice: An Activity based Approach, Sage, London.

Jarzabkowski, P. and Spee, A.P. (2009) 'Strategy-as-practice: a review and future directions for the field', International Journal of Management Reviews, Vol. 11, No. 1, pp.69-95.

Jarzabkowski, P., Balogun, J. and Seidl, D. (2007) 'Strategizing: the challenges of a practice perspective', Human Relations, Vol. 60, No. 1, pp.5-27. 
Jarzabkowski, P., Lê, J. and Van de Ven, A.H. (2013) 'Responding to competing strategic demands: How organizing, belonging, and performing paradoxes coevolve', Strategic Organization, In press.

Johnson, G., Melin, L. and Whittington, R. (2003) 'Micro strategy and strategizing: towards an activity-based view?', Journal of Management Studies, Vol. 40, No. 1, pp.3-22.

Kipping, M. and Kirkpatrick, I. (2013) 'Alternative pathways of change in professional services firms: the case of management consulting', Journal of Management Studies, Vol. 50, No. 5 , pp.777-807.

Kornberger, M. and Clegg, S. (2011) 'Strategy as performative practice: the case of Sydney 2030', Strategic Organization, Vol. 9, No. 2, pp.136-162.

Kylänen, M. and Rusko, R. (2011) 'Unintentional coopetition in the service industries: the case of Pyhä-Luosto tourism destination in the Finnish Lapland', European Management Journal, Vol. 29, No. 3, pp.193-205.

Laine, P.M. (2010) Toimijuus strategiakäytännöissä: diskurssi-ja käytäntöteoreettisia avauksia. Turun kauppakorkeakoulu/Turku School of Economics, Sarja/Series A-1.

Laine, P.M. and Vaara, E. (2007) 'Struggling over subjectivity: a discursive analysis of strategic development in an engineering group', Human Relations, Vol. 60, No. 1, pp.29-58.

Lewin, K. (1947) 'Frontiers in group dynamics II. Channels of group life; social planning and action research', Human Relations, Vol. 1, No. 3, pp.143-153.

Lundin, R.A. and Söderholm, A. (1995) 'A theory of the temporary organization', Scandinavian Journal of Management, Vol. 11, No. 4, pp.437-455.

Luo, Y. (2004) Coopetition in International Business, Copenhagen Business School Press, Copenhagen.

MacLean, D. and MacIntosh, R. (2012) 'Strategic change as creative action', International Journal of Strategic Change Management, Vol. 4, No.1, pp.80-97.

Mautner, G. (2005) 'Time to get wired: using web-based corpora in critical discourse analysis', Discourse and Society, Vol. 16, No. 6, pp.809-828.

Meynell, F. (2005) 'A second-order approach to evaluating and facilitating organizational change', Action Research, Vol. 3, No. 2, pp.211-231.

Miller, K.D. and Tsang, E.W. (2011) 'Testing management theories: critical realist philosophy and research methods', Strategic Management Journal, Vol. 32, No. 2, pp.139-158.

Mintzberg, H., Ahlstrand, B. and Lampel, J. (1998) Safari Strategy: A Guided Tour through the Wilds of Strategic Management, The Free Press, New York.

Monteiro, G.F.A. and Pianna, A. (2012) 'Institutional change and capability building: some remarks on the institutional-based view of strategy', International Journal of Strategic Change Management, Vol. 4, No. 1, pp.52-67.

Ordóñes de Pablos, P. (2004) 'The nurtune of knowledge-based resources through the design of an architecture of human resource management systems: implications for strategic management', International Journal of Technology Management, Vol. 27, Nos. 6-7, pp.533-543.

Orlikowski W (2000) 'Using technology and constituting structure: a practice lens for studying technology in organizations', Organization Science, Vol. 11, No. 4, pp.404-428.

Orlikowski, W. (1992) 'The duality of technology: rethinking the concept of technology in organizations', Organization Science, Vol. 3, No. 3, pp.398-427.

Orr, J.E. (1996) Talking about Machines: An Ethnography of a Modern Job, Cornell University Press, Ithaca, NY.

Osborne, P. and Ballantyne, D. (2012) 'The paradigmatic pitfalls of customer-centric marketing', Marketing Theory, Vol. 12, No. 2, pp.155-172.

Pettigrew, A.M., Woodman, R.W. and Kim, S. Cameron, K.S. (2001) 'Studying organizational change and development: Challenges for future research', Academy of Management Journal, Vol. 44, No. 4, pp.697-713. 
Ramsey, C. (2014) 'Management learning: a scholarship of practice centred on attention?', Management Learning, Vol. 45, No. 1, pp.6-20.

Rojek, C. and Turner, B. (2000) 'Decorative sociology: towards a critique of the cultural turn', The Sociological Review, Vol. 48, No. 4, pp.629-648.

Romme, G. and Dillen, R. (1997) 'Mapping the landscape of organizational learning', European Management Journal, Vol. 15, No. 1, pp.68-78.

Rosenau, P.V. (2003) The Competition Paradigm: America's Romance with Conflict, Contest, and Commerce, Rowman \& Littlefield, USA.

Rowe, C. (1996) 'Evaluating management training and development: revisiting the basic issues', Industrial and Commercial Training, Vol. 28, No. 4, pp.17-23.

Rusko, R. (2012) 'Strategic processes and turning points in ICT business: case Nokia', International Journal of Innovation in the Digital Economy, Vol. 3, No. 3, pp.25-34.

Schatzki, T.R., Cetina, K.K. and Savigny, E. (2001) The Practice Turn in Contemporary Theory, Routledge, London.

Senge, P.M. (1990) The Fifth Discipline: The Art and Practice of the Learning Organization, Doubleday, New York.

Sorama, K. (2008) Oppiminen yritysten kahdenvälisen yhteistyösuhteen kontekstissa. Toimittajan oppiminen metalliteollisuuden alihankintasuhteissa (Learning in the Context of Bilateral Cooperation Relationships between Companies. The Supplier's Models of Learning in Subcontracting Relationships in the Metal Industry), Acta Wasaensia No. 185.

Styhre, A. (2002) 'Non-linear change in organizations: organization change management informed by complexity theory', Leadership \& Organization Development Journal, Vol. 23, No. 6, pp.343-351.

Suddaby, R., Seidl, D. and Lê, J.K. (2013) 'Strategy-as-practice meets neo-institutional theory', Strategic Organization, Vol. 11, No. 3, pp.329-344.

Tsai, W. (2002) 'Social Structure of 'coopetition' within a multiunit organization: coordination, competition, and intraorganizational knowledge sharing', Organization Science, Vol. 13, No. 2, pp.179-190.

Walley, K. (2007) 'Coopetition: an introduction to the subject and an agenda for research', International Studies of Management and Organization, Vol. 37, No. 2, pp.11-31.

Watzlawick, P., Weakland, J.H. and Fisch, R. (1974) Change: Principles of Problem Formation and Problem Resolution, Norton, New York.

Whittington, R. (1996) 'Strategy as practice', Long Range Planning, Vol. 29, No. 5, pp.731-735.

Whittington, R. (2003) 'The work of strategizing and organizing: for a practice perspective', Strategic Organization, Vol. 1, No. 1, pp.117-126.

Whittington, R. (2006) 'Completing the practice turn in strategy research', Organization Studies, Vol. 27, No. 5, pp.613-634.

Zundel, M. (2013) 'Walking to learn: rethinking reflection for management learning', Management Learning, Vol. 44, No. 2, pp.109-126. 